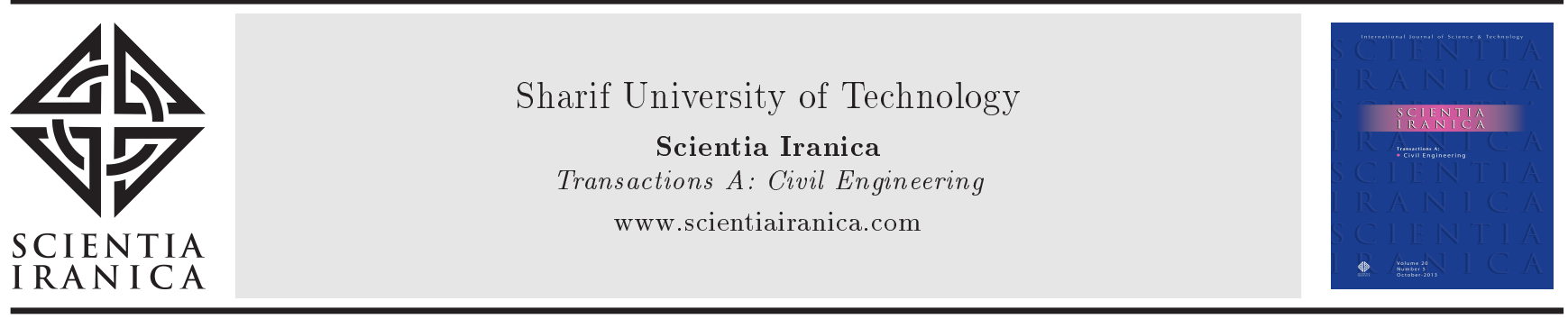

\title{
Wind turbines design corrections for next Galicia climatic conditions
}

\author{
J.A. Orosa ${ }^{a}$, Á.M. Costa ${ }^{a}$, G. Roshan ${ }^{b, *}$ and E.J. García-Bustelo ${ }^{a}$ \\ a. Departamento de Energía y P. M. Escuela Técnica Superior de N. y M. Universidade da Coruña. M. Paseo de Ronda, 51, \\ 15011. A Coruña. \\ b. Department of Geography, Golestan University, Shahid Beheshti, Gorgan, P.O. Box 49138-15759, Iran.
}

Received 27 June 2015; received in revised form 9 January 2016; accepted 7 March 2016

\section{KEYWORDS}

Wind energy;

Climate change;

Moist air;

Power;

Wind farm.

\begin{abstract}
Galicia, placed in northwest of Spain, is a clear example of global wind energy development as a consequence of its climate conditions. Despite this fact, previous research works have indicated a climate change in the next years that must be considered at the time of wind turbine design, selection, and placement. In this work, information about weather conditions and power output from twenty four wind turbines was sampled in a typical year, and a statistic study was done. Based on this information, a model that relates weather to power conversion in this particular region and wind turbines model was obtained. This particular procedure lets us define the effect of climate change over wind power on Galician wind farms. Results showed a $10 \%$ power output fall during spring and summer seasons. Therefore, future studies about new technologies that work out well under those conditions, such as low wind turbines, must be done. At the same time, results can be employed for future wind turbines placement optimization. Finally, nowadays, there is no standard or procedure to consider this highly complex situation, and so the present work aims to be the initial guide.

(C) 2017 Sharif University of Technology. All rights reserved.
\end{abstract}

\section{Introduction}

European weather starts from the Atlantic, and consequently, what happens over there determines the weather and climate of Europe to a large extent. To be more precise, Galicia is located in northwest of Spain where the climate is mild and mainly influenced by the Azores anticyclone, the Iceland depression, and the central Europe thermal anticyclone.

As a result of this climate, regions, such as Jylland in Denmark and Galicia, are notable as the leading global wind energy development and grid integration. It is known that wind-powered future would mean reducing risks related to fossil and nuclear fuels. Not

*. Corresponding author. Tel.: 01732254260;

Fax: 01732254260

E-mail address: ghr.roshan@gu.ac.ir (G. Roshan) only does wind power involve no geo-political risk, but also it reduces external energy dependence and the need for energy imports together with no fuel costs, no fuel price risk, no resource constraints, no $\mathrm{CO}_{2}$, or any other harmful emissions or radioactive waste [1].

On the other hand, recent papers [2-5] have shown that climate change might alter this situation due to wind turbines' power conversion which depends mainly on moist air density and wind velocity. For example, nowadays, wind turbines farms are selected according to wind frequency [6] and direction, but if we consider the maximum power a wind turbine can convert from a free air stream, then we can draw the conclusion that moist air density can affect this issue, and then the climate change is sure to follow.

As a consequence, the effect of the climate change can involve an error on wind turbine selection and its behaviour once it is put in. These effects are really 
significant when we consider the fact that a contribution [7] of the wind energy to the European electricity consumption of about $22.6 \%$ (965 TWh) by 2030 is expected, and the average size of a wind turbine will be $2 \mathrm{MW}$ onshore and $10 \mathrm{MW}$ offshore. Then, only 90,000 turbines (75,000 onshore and 15,000 offshore) would be needed to fulfill the $300 \mathrm{GW}$ target. Furthermore, being the technical lifetime for a turbine twenty years onshore and twenty-five years offshore, it is the right time to consider new development pathways, such as lower moist air density and low speed wind turbines.

Taking previous field reports as reference [8], in this paper, twenty-four wind turbines are analysed in a typical year to get a model that relates weather to power conversion. Once that model is achieved, the climate change is assessed in wind turbines in Galicia.

\section{Materials and methods}

In this paper, a farm with twenty-four wind turbines was tested during a typical year under different weather conditions. Once this was achieved, this model was employed to explain the climate change with wind turbines.

\subsection{Climatic data}

The climatic data were sampled in 50 weather stations located in the main interesting points in Galicia, as we can see in Table 1 . Its climate is affected by the Atlantic Ocean winds, Siam 2008 [9].

In previous research works [10], it is shown that climate change is more than temperature, and other parameters, such as wave height, can be among the affective factors. In our case, wind power can be directly related to relative humidity and wind velocity. In consequence, these meteorological stations show variables, such as temperature, relative humidity, and wind speed, among others, with a sample frequency from about five to ten minutes. Furthermore, its temperature, relative humidity, and wind velocity margin of error are of $0.1^{\circ} \mathrm{C}, 0.2 \%$, and $0.1 \mathrm{~m} / \mathrm{s}$, respectively.

Finally, these weather stations have been chosen for this study due to the fact that they avoid the buildings and other parameters that could interfere with the sample data, according to ASHRAE 2005 measuring conditions. In consequence, their height and placement are considered adequate for wind speed observation [11].

\subsection{Climatic change predictions}

Models of climatic change were obtained from references after a curve fit for each season, according to Eqs. (1) to (4). Each equation shows the average temperature rise in Galicia for the last thirty years regarding the average value of $13.63^{\circ} \mathrm{C}$ in 1987 :

$$
\Delta t_{\text {winter }}=0.05 . \tau
$$

$$
\begin{aligned}
& \Delta t_{\text {spring }}=0.07 . \tau, \\
& \Delta t_{\text {summer }}=0.05 . \tau, \\
& \Delta t_{\text {Autumn }}=0.03 . \tau,
\end{aligned}
$$

where $\Delta t$ is the mean seasonal temperature increment $\left({ }^{\circ} \mathrm{C}\right)$; and $\tau$ is the time (years).

Once these models are obtained, they can be used to predict the climate change in Galicia for the next twenty years. The year 2030 was chosen due to the high expectancy of the wind energy contribution from the wind turbines to the European electricity and also because wind turbines have an average technical lifetime of twenty years.

\subsection{Effect of moist air density on wind power} As it was already mentioned, the aim of this research is to show the relationship between climatic conditions and the wind power conversion. In order to provide a reference for this power output, it will be compared to the power of the free-air stream, which flows through the same cross-sectional area $\mathrm{A}$, without extracting the mechanical power. On the other hand, ASHRAE psychometric equations let us define moist air specific volume, as shown in Eq. (5) [12].

$$
v=0.29 \cdot \frac{T}{P} \cdot(1+1.6078 . W),
$$

where $W$ is the humidity ratio $(\mathrm{kg} / \mathrm{kg}) ; T$ is the mean temperature $(\mathrm{K})$; and $P$ is the total pressure $(\mathrm{Pa})$.

Finally, we must remember that the moist air density is the inverse of its specific volume, according to Eq. (6):

$$
\rho=\frac{1}{v}
$$

where $\rho$ is the moist air density $\left(\mathrm{kg} / \mathrm{m}^{3}\right)$.

The software EES (Engineering Equation Solver) was employed to automate the process during the design process.

\subsection{Curve fit}

Once the real annual samples of the wind power conversion data were obtained from wind farms, they were related to the weather conditions during the same year by the statistical software SPSS 11.0. In particular, a $3 \mathrm{D}$ curve fit was designed to define an adequate model that would enable us to predict the future wind power production. The results are shown in Figure 1.

\section{Results and discussion}

As it was explained in advance, this paper relates real wind turbine power conversion to climate, weather, and future climate change that will have effect on the wind turbines design, their location, and their power conversion. Hourly climatic conditions in wind 
Table 1. Weather stations coordinates and altitude.

\begin{tabular}{|c|c|c|c|}
\hline Weather station & UTMX-29T & UTMY-29t & Altitude (m) \\
\hline CIS Ferrol & 560575 & 4815596 & 35 \\
\hline Corrubedo-A & 497788 & 4711340 & 30 \\
\hline Fontecada-A & 510673 & 4757523 & 365 \\
\hline Mabegondo-A & 560035 & 4787795 & 98 \\
\hline Marco da Curra-A & 589723 & 4799415 & 645 \\
\hline Melide-A & 583063 & 4751027 & 475 \\
\hline Monte Xalo-A & 548165 & 4787002 & 510 \\
\hline Muíños & 502146 & 4764251 & 490 \\
\hline Muralla-A & 518434 & 4732856 & 650 \\
\hline Olas-A & 558736 & 4775147 & 401 \\
\hline Río do Sol & 525478 & 4770587 & 340 \\
\hline Santiago-Físicas-A & 535915 & 4747144 & 255 \\
\hline Sergude & 544164 & 4741185 & 226 \\
\hline Campus Lugo-A & 618765 & 4761198 & 420 \\
\hline Conchada & 641837 & 4705345 & 600 \\
\hline Folgueira de Aigas & 669976 & 4758503 & 910 \\
\hline Fragavella-A & 625715 & 4812475 & 605 \\
\hline Guitiriz-A & 598922 & 4786880 & 690 \\
\hline Marroxo-A & 623291 & 4703593 & 630 \\
\hline Monte Panda & 641017 & 4778172 & 605 \\
\hline O Xipro & 660504 & 4782755 & 840 \\
\hline Os Ancarea-A & 669920 & 4742923 & 1365 \\
\hline Pedro Murias A & 654986 & 4822541 & 45 \\
\hline Sambreixo & 598550 & 4777692 & 498 \\
\hline Santalla & 645239 & 4737385 & 720 \\
\hline Serra Vacaloura & 601970 & 4741768 & 795 \\
\hline Xunqueira & 612845 & 4834430 & 15 \\
\hline Alto do Rodicio-A & 616296 & 4683835 & 962 \\
\hline As Petarelas & 670470 & 4703269 & 555 \\
\hline Baltar & 606369 & 4643587 & 820 \\
\hline Castelo da Pena & 636358 & 4642815 & 670 \\
\hline $\mathrm{O}$ invernadeiro- $\mathrm{A}$ & 636971 & 4664276 & 1020 \\
\hline O Xurés & 584682 & 4639012 & 1000 \\
\hline Pedreiriño & 573955 & 4643896 & 720 \\
\hline Pieles & 585455 & 4708064 & 680 \\
\hline Serra do Eixe & 664341 & 4691308 & 1225 \\
\hline Verín-A & 632770 & 4648322 & 555 \\
\hline Arcos da Condesa & 531354 & 4173851 & 145 \\
\hline Carballedo & 541735 & 4702509 & 350 \\
\hline Castro Vicaludo & 511413 & 4649371 & 450 \\
\hline Castrove-A & 524471 & 4701077 & 415 \\
\hline Corón-A & 520514 & 4714577 & 7 \\
\hline Cuntis & 533209 & 4721465 & 265 \\
\hline Fornelos de Montes-A & 550571 & 4685361 & 759 \\
\hline Illas Cíes & 508050 & 4674377 & 15 \\
\hline Lourizán-A & 527746 & 4695497 & 60 \\
\hline Monte Aloia-A & 526608 & 4658156 & 410 \\
\hline Mouriscade-A & 570877 & 4718272 & 501 \\
\hline Pereira & 555880 & 4720398 & 715 \\
\hline Queimadelos-A & 547276 & 4675193 & 360 \\
\hline
\end{tabular}

turbines farm were sampled with real wind power. The temperature, the relative humidity, the wind velocity, and the wind power conversion were sampled for each season of the last few years. These figures prove that climatic conditions are mild with a high mean relative humidity of $80 \%$ during the whole year. The temperature shows a clear variation between winter and summer seasons from $4^{\circ} \mathrm{C}$ in winter to $14^{\circ} \mathrm{C}$ in summer. Wind velocity ranges from $4 \mathrm{~m} / \mathrm{s}$ to $12 \mathrm{~m} / \mathrm{s}$ mainly in the winter season. These values are in 


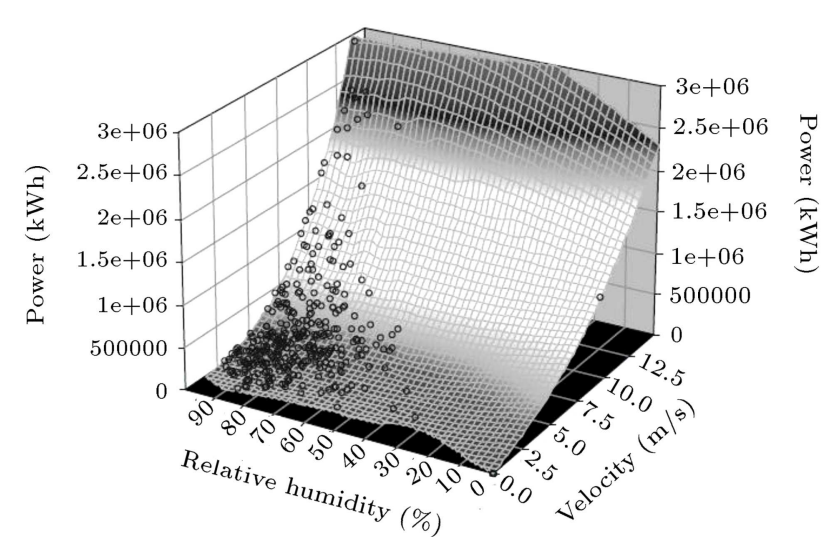

Figure 1. Curve fit among the wind power, the wind velocity, and the moist air density.

agreement with previous research works about the ocean wind energy resource and trends [13-14], and all these variables will simultaneously influence the wind power obtained.

After studying the climatic conditions and the wind power conversion in the past year, it is interesting to settle its relationship. To prove it, a 3D fit of real sample data was done to relate the power conversion and climatic conditions of temperature and relative humidity, expressed as moist air density, in a wind turbine farm. Results proved the adequate model as a function of moist air density and a cube of wind velocity for a correlation factor of 0.99 , as seen in Figure 1 and Eq. (7):

$$
P_{\text {ow }}=-249492.18+21722274 . \rho+1128.9655 . V^{3},
$$

where $P_{\text {ow }}$ is the wind power $(\mathrm{kWh}) ; \rho$ is the moist air density $\left(\mathrm{kg} / \mathrm{m}^{3}\right)$; and $V$ is the wind velocity $(\mathrm{m} / \mathrm{s})$.

The resulting model presents some constants that consider real factors, such as ambience and wind turbine characteristics. This model could be employed to predict that power conversion can respect climatic conditions. The average temperatures and the wind velocity for the last ten years are represented in Figures 2 and 3 , and its corresponding power conversion is shown in Figure 4 for each season, according to the resulting model.

These figures prove that seasonal climatic conditions respect the wind power conversion. Figure 2 shows the annual mean temperature of the wind farm zone for each different season. Therefore, the mean temperature in the summer shows its higher value at about $16^{\circ} \mathrm{C}$, and in winter, it is at $7^{\circ} \mathrm{C}$. Autumn and spring seasons present intermediate values of 13 and $11^{\circ} \mathrm{C}$, respectively.

On the other hand, mean wind farm seasonal velocity is shown in Figure 3 . This figure shows a summer mean velocity of $3.5 \mathrm{~m} / \mathrm{s}$ that is the lowest value compared to $5.5 \mathrm{~m} / \mathrm{s}$ in the other seasons.

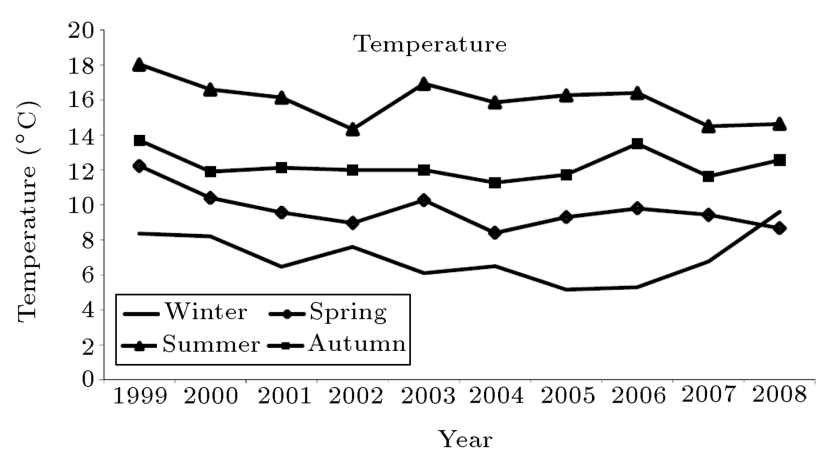

Figure 2. Seasonal mean temperature of the last ten years.

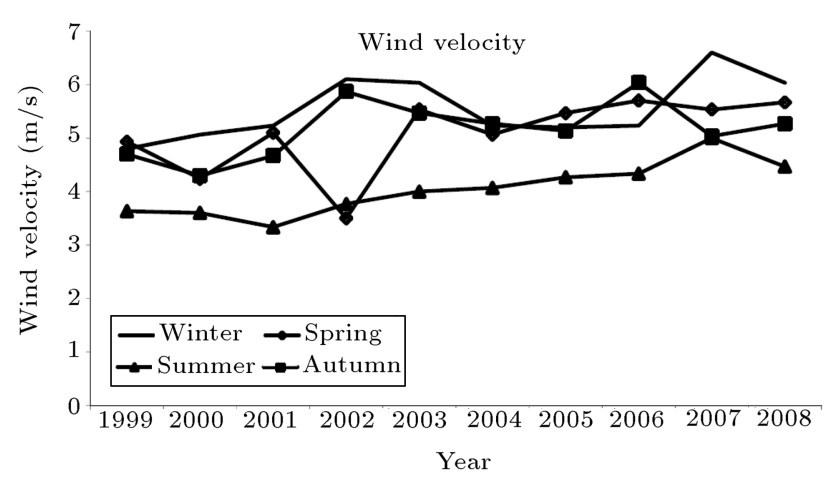

Figure 3. Seasonal mean wind velocity of the last ten years.

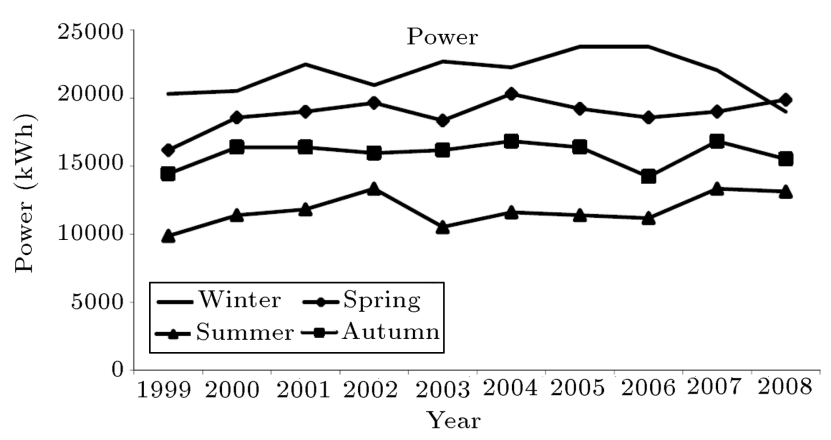

Figure 4. Seasonal mean power conversion of the last ten years.

This mean velocity is a consequence of the Azores anticyclone, as explained before.

In Figure 4, it can be seen that a mean value is similar to the nominal power obtained during spring and autumn seasons. This power rises to a value of $20 \mathrm{MWh}$ during the winter. Finally, during the summer time, this wind power is experimented in a clear fall regarding the other seasons with a mean value of $10 \mathrm{MWh}$. These curves let us understand that although the mean wind velocity is nearly the same in spring as it is in autumn, it will be the mean temperature as the one that controls the wind power conversion. This effect will be present when we try to predict the climate effect on wind power conversion, because a temperature rise as a consequence of the 


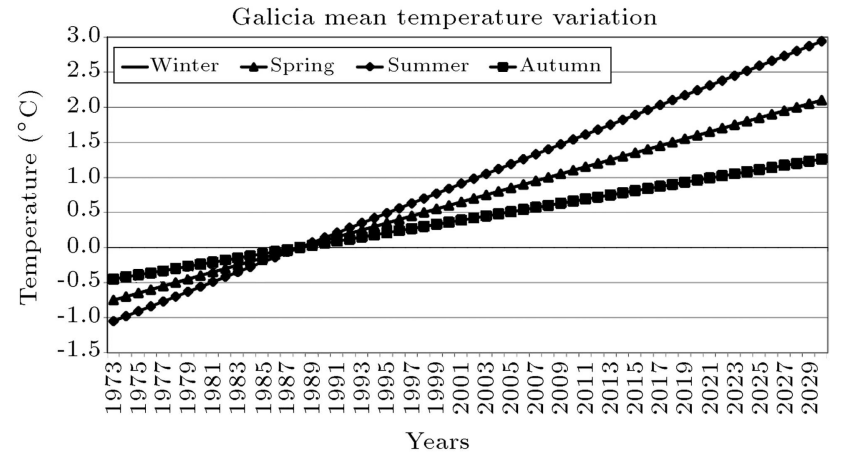

Figure 5. Mean Galicia temperature evolution during the last years.

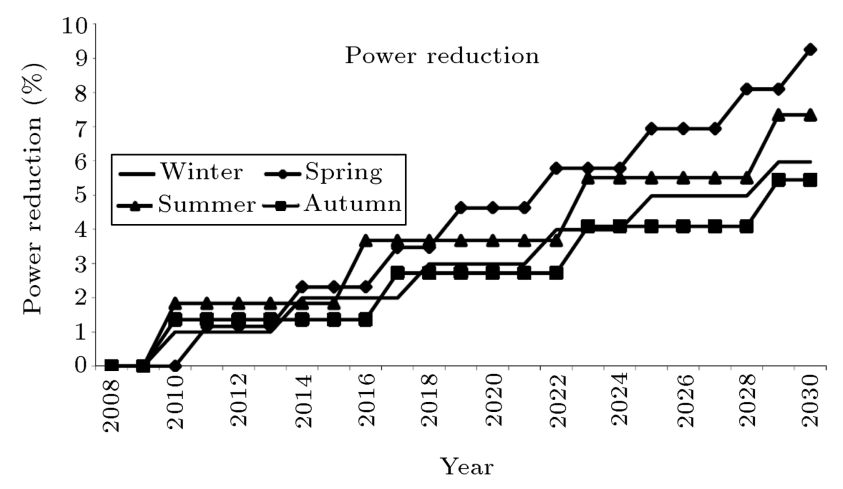

Figure 6. Power reduction percentage in the next few years.

climate change will modify wind power production in these years if the same wind turbines would still be working. Therefore, once the relationship between climate and wind power conversion is proved, it is interesting to know which climate will effect on wind turbines production. The references showed four linear adjustments in the average temperature rise during the last few years that let us predict the future mean temperature for each season, as seen in Figure 5 and in Eqs. (1) to (4). It is interesting to point out that the winter and summer seasons show the same annual temperature rise ratios, although the highest rise is shown in the spring time. This temperatures rise will involve a value of $3,2.1$, and $1.3^{\circ} \mathrm{C}$ in spring, winter, and autumn seasons by 2030, respectively, as seen in Figure 5. These values of temperature, mean relative humidity, and wind velocity are introduced in the resulting model, showing that the highest power reduction reaching a value of $9 \%$ by 2030 will happen in the springtime and that in the summer it will be about $7 \%$. In winter and autumn winds, the power reduction will be about $6 \%$ of the current farm wind power, as we can see in Figure 6.

If we consider that there are not any wind turbines operating by 2030 due to the fact that the technical lifetime for a turbine is twenty years onshore and twenty-five years offshore, then it is the right time to consider new development pathways that could yield very great returns for technology. We should also consider the diversity of turbine types and materials used twenty years ago, which proves this point. The small wind energy sector is just one example of a leviathan starving to death for the lack of a longterm research [15-18]. A lower moist air density and a higher frequency of extreme wind velocities should be considered when it comes to research studies.

These low speed wind turbines must be analysed with different rotors, such as the Savonius rotors [1922 ], and this should be done in depth in future papers.

\section{Conclusions}

In this paper, real wind farm power conversion was sampled during a typical year simultaneously with climatic conditions. As a consequence of these mean values, wind power conversion shows maximum mean value during the winter season and minimum mean during the summer as a result of its mean wind velocity. Furthermore, the A 3D model was obtained and tested under predicted temperature. Results showed that the highest power reduction reaching a value of $9 \%$ by 2030 would happen in the spring season, and that it will be about $7 \%$ in the summer. In winter and autumn, the wind power reduction will be about $6 \%$ of the current farm wind power.

Finally, we must remember that wind power can make a substantial contribution to the EU emission reduction targets under the Kyoto protocol. The wind could comply with the $30 \%$ of the Union's obligation by 2010 if there is enough emphasis on the technological R\&D and market development. Therefore, if we consider that nowadays there are not any wind turbines operating by 2030 due to the fact that the technical lifetime for a turbine is twenty years onshore and twenty-five years offshore, then it is the right time to consider new development pathways that could yield very great returns for the technology like low speed wind turbines.

\section{Acknowledgements}

We would like to thank the Instituto Enerxético de Galicia (INEGA), Parque Eólico Experimental de Sotavento and MeteoGalicia for technical support of this work.

\section{References}

1. Wesker, E. "Climate change; a summary of some present knowledge and theories", http://www.euronet. nl/users/e_wesker/climate.html (Acceded January 2011).

2. Naranjo, L. and Vicente, E.A. "Natural climate vari- 
ability in Galici", MeteoGalicia.Xunta de Galicia e fundación Caixa Galicia. Ed. Consellería de Medio Ambiente e Desenvolvemento Sostible, pp. 1-292 (2006).

3. "Climate change 2001: Working group I: The scientific basis", http://www.grida.no/publications/ other/ipcc\%5Ftar/?src=/CLIMATE/IPCC_TAR/ WG1/042.htm. (Acceded January 2011).

4. McCarthy, J.J., Canziani, O.F., Leary, N.A., Dokken, D.J. and White, K.S., IPCC Technical Summary. Climate Change. Editors Impacts, Adaptation and Vulnerability. A Report of Working Group II of the Intergovernmental Panel on Climate Change, Cambridge University Press, pp. 1-1000 (2001).

5. Sailor, D.J., Smith, M. and Hart, M. "Climate change implications for wind power resources in the Northwest United Status", Renewable Energy, 33, pp. 2393-2406 (2008).

6. Carta, J.A. and Mentado, D. "A continuous bivariate model for wind power density and wind turbine energy output estimations", Energy Converse Management, 48, pp. 420-432 (2007).

7. European Wind Energy Technology Platform, Wind Energy: A Vision for Europe in 2030, pp. 1-24 (2008).

8. Jacobson, R., Meadors, E. and Link, H., NREL. Power Performance Test Report for the AOC 15/50 wind turbine, Test B in Golden, Colorado. Conducted for United States Department of Energy by National Wind Technology Centre, National Renewable Energy Laboratory, pp. 1-150 (2003).

9. MeteoGalicia "Climatological data of Galicia", Consellería de Medio Ambiente, Xunta de Galicia, pp. 1124 (2007).

10. Young, I.R., Zieger, S. and Babanin, A.V. "Global trends in wind speed and wave height", Science, 332(6028), pp. 451-455 (2011).

11. Thomas, B.R., Kent, E.C., Swail, V.R. and Berry, D.I. "Trends in ship wind speeds adjusted for observation method and height", International Journal of Climatology, 28, pp. 747-763 (2008).

12. ASHRAE, ASHRAE Handbook Fundamentals (Spanish Edition), American Society of Heating, Refrigerating and Air-Conditioning Engineers, Atlanta (1988).

13. Zheng, C.W. and Li, C.Y. "Variation of the wave energy and significant wave height in the China sea and adjacent waters", Renewable and Sustainable Energy Reviews, 43, pp. 381-387 (2015).

14. Zheng, C.W. and Pan, J. "Assessment of the global ocean wind energy resource", Renewable and Sustainable Energy Reviews, 33, pp. 382-391 (2014).
15. Shikha, S., Batí, T.S. and Kpthari, D.P. "A new vertical axis wind rotor using convergent nozzles", Large Engineering Conference on Power Engineering, pp. 177-181 (2003).

16. Shikha, S., Bhatti, T.S. and Kothari, D.P. "Air concentrating nozzles: a promising option for wind turbines", International Journal of Energy Technology and Policy, 3(4), pp. 394-412 (2005).

17. Shikha, S., Bhatt, T.S. and Kothari, D.P. "The evolution of wind power technology - a review", IE(I) Journal-ID, pp. 84, 4-9 (2007).

18. Altan, B.D., Atildan, M. and Özdamar, A. "An experimental study on improvement of Savonius rotor performance with curtaining", Experimental Thermal and Fluid Science, 32, pp. 1673-1678 (2008).

19. Sabzevan, A. "Performance characteristics of concentrator augmented Savonius wind rotors", Wind Engineering, 1, pp. 198-206 (1977).

20. Wittwer, A.R. and Möller, S.V. "Characteristics of the low-speed wind tunnel of the UNNE", Journal of Wind Engineering \& Industrial Aerodynamics, 85, pp. 307320 (2000).

21. Saha, U.K., Thola, S. and Maity, D. "Optimum design configuration of Savonius rotor through wind tunnel experiments", Journal of Wind Engineering \& Industrial Aerodynamics, 96, pp. 1359-1375 (2008).

22. Saha, U.K. and Rajkumar. R. "On the performance analysis of Savonius rotor with twisted blades", Renewable Energy, 31, pp. 1776-1788 (2006).

\section{Biographies}

José A. Orosa was graduated in Marine Engineer and Naval Architecture at the University of A Coruña. $\mathrm{He}$ is the prize winner of the Spanish Marine Engineer Studies. Nowadays, he is Director of the Department of Energy of the University of A Coruña. During last years, he participated in the International Energy Agency Annex 41 and collaborated with the INEGA and IDEMEC of the University of Porto.

Ángel M. Costa is graduated in Marine Engineer and received a Master degree in Maritime Engineering. His $\mathrm{PhD}$ showed the link between weather conditions and failures in wind farms based on new statist procedures. Presently, he is a Full Professor and Researcher of the Department of Energy of the University of A Coruña (Spain) about wind energy conversion and management. During the last years, he participated in national and international research works about wind energy conversion and management in collaboration with the International Energy Agency (IEA).

Gholamreza Roshan received the $\mathrm{PhD}$ degree in Physical Geography field of climatology from University of Tehran, Tehran, Iran, in 2011. He is currently 
an Assistant Professor in Golestan University, Gorgan, Iran. His research interests lie in the climate change, global warming, biometeorology, and climate modeling. He has published more than 60 peer-reviewed publications and conference papers in his field as well as some technical reports for various public and private agencies. Also, he has been selected as a top professor in 2013, 2014, and 2015 years by Golestan University.

Enrique Juan García-Bustelo received his BS and
MS in Marine Engineer from the University of A Coruña and Master in Marine Engineering. After that, as Marine Engineer, he received a great professional experience in power stations and thermodynamically processes. Currently, he is Full Professor and Researcher at the Department of Energy of the University of A Coruña. His $\mathrm{PhD}$ showed a new procedure for energy conversion under low wind velocities. In last years, his research topic has been centred on moist air modelling and new applications. 